GEOLOGICAL SURVEY CIRCULAR 792

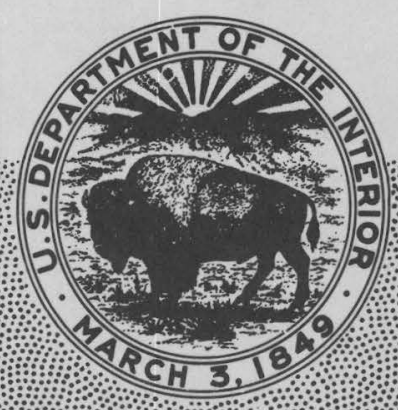

Background Information to Accompany the Atlas of Some Metal and Nonmetal Mineral Provinces in the Conterminous United States 

Background Information to Accompany the Atlas of Some Metal and Nonmetal Mineral Provinces in the Conterminous United States

By Edwin W. Tooker

GEOLOGICAL SURVEY CIRCULAR 792 


\section{United States Department of the Interior}

\section{CECIL D. ANDRUS, Secretary}

\section{Geological Survey}

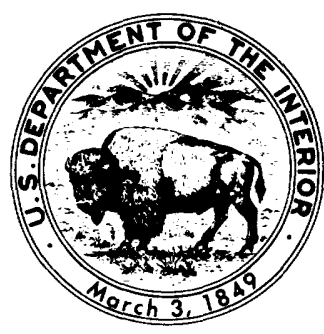

H. William Menard, Director

\section{Library of Congress Cataloging in Publication Data}

Tooker, Edwin Wilison, 1923-

Background information to accompany the atlas of some metal and nonmetal mineral provinces in the conterminous United States.

(Circular - U. S. Geological survey ; 792)

A companion report to maps for individual commodities in the open-file report series of the U. S. Geological Survey.

Supt. of docs. no.: I 19.4/2:792

1. Mines and mineral resources--United States. 2. Geology--United States. I. Title. II. Series: United States. Geological Survey. Circular ; 792. QE75.C5 no. 792 [TN23] 557.3s [553'.0973] 80-607020 


\section{CONTENTS}

Introduction

What is a mineral province map?

Components of province maps

Use and users of province maps

Limitations and revision of province maps

A common denominator for resource evaluation

Comments on resource terminology used

What are critical minerals?
Page

1

2

2

5

5

6

7

8
A need for concern about domestic resources

Page

The present mineral-resource situation

The problem: presence in the Earth's crust versus deliverability ..................................... 11

Good resource data-more than an inventory _..._._... 12

Relevance of geologic knowledge to mineral availability and metal and nonmetal mineral provinces_._._._.- 12

References cited (-........ 14

\section{ILLUSTRATIONS}

1. Diagram illustrating role of nonfuel minerals in U.S. economy, with estimated values for 1977

1. Diagram illustrating role of nonfuel minerals in U.S. economy, with estimated values for 1977

3. Diagram showing generalized projection of mineral supply and consumption

\section{TABLES}

TABLE 1. Comparisons of size, value, and numbers of depos.ts for selected critical commodities, and their availability and import dependence in the United States

2. Net import dependence of selected minerals and metals in 1975

3. Relative age spans of major geologic units used in this report and in province map discussions 



\title{
Background Information to Accompany the Atlas of some Metal and Nonmetal Mineral Provinces in the Conterminous United States
}

\author{
By Edwin W. Tooker
}

\section{INTRODUCTION}

The principal purpose of this companion report to the atlas of metal and nonmetal mineral provinces is to discuss the rationale for making the maps, the methodology used in their construction, their characteristics and use, the serious gaps in presently available resource information, the definition of some commonly used geologic concepts and terms, and the important role of geology in identifying favorable areas for future resources. Maps for individual commodities are available for public inspection in the Open-File Report series of the U.S. Geological Survey (Open-File Report 79-576).

The mineral provinces shown in this series of maps for a selected group of critical metal and nonmetal commodities represent areas of the 48 conterminous United States in which there are present mining activity, past production, indication, or reasonable expectation of undiscovered minable minerals, and (or) reported but possibly not fully evaluated mineral occurrences. The maps summarize present resource-availability information along with the individual authors' evaluations; the data base is the published commodity literature, including resource data and analyses by U.S. Geological Survey mineral specialists. A somewhat comparable composite metal-province map for Alaska was prepared by Clark and others (1974). Because so much information is available on individual metal and nonmetal commodities in the conterminous United States, as well as on their geologic availability, the scope of this atlas has been broadened to include maps of individual commodities that present both the basic data and a brief description of the provinces recognized.
A mineral province map is a simplified level I evaluation (U.S. Geological Survey, 1975, p. 19) of the current status of knowledge about the areal distribution and geologic environment of mineral commodities, whether as: (1) primary minerals (major products of the material mined), (2) coproduct minerals (less abundant primary products sought in a multicommodity deposit), (3) byproduct minerals (secondarily produced, often serendipitously, from the production of a primary mineral), (4) available subeconomic mineral materials, or (5) reported but unevaluated occurrences of any of the above types. The mineral province maps in the atlas seek to extend the scope of previous commodity maps, which emphasized the distribution, size, and variety of types of known productive deposits, and to evaluate their supply potential in terms of current economic source deposits and recognized geologic factors.

Any evaluation of future resources must also consider those yet-unrecognized or currently unused (subeconomic) resource materials that may be extracted from lower grade, coproduct, and byproduct minerals now considered unminable or waste. The limited scope of a level I evaluation and the small scale of the accompanying maps make it possible to highlight only a few of the geologic features that represent important genetic associations in the occurrence of metal and nonmetal deposits. This very general picture must be considered a first step toward unraveling the complex metallogenetic relations that need to be well understood in order to recognize new resource possibilities and to develop new mineral exploration technology. 
All the statistical and economic information derives from: (1) "Mineral facts and problems, 1975 edition" (U.S. Bureau of Mines, 1976a), which provided economic resource-availability summaries through 1974, and "Commodity data summaries 1979" (U.S. Bureau of Mines, 1979), which provided data through 1978; (2) an international survey of major producing mines in the world (Mining Magazine, 1976), which identified large mines active in 1975 in the conterminous United States; and (3) "United States mineral resources" (Brobst and Pratt, 1973), which contains the most recent discussions on and estimates of geologically available resource materials.

The data depicted on the mineral province maps are intended primarily to assist the reader in becoming more aware of some of the basic resource-availability issues that underlie present and future U.S. needs for critical raw materials. Mineral provinces, for example, may overlap areas of public interest in which State and Federal governmental decisions on land use must be made. Also, the full geologic significance of mineral-resource values must be understood beyond present economic evaluations so that, in time of need, the sources and availability of all types of critical resources will be known. This broadened perception will permit more intelligent balancing of mineral-resource values against such competing factors as ecology, scenic or historic preservation, recreational use, or other economic and esthetic considerations.

\section{WHAT IS A MINERAL PROVINCE MAP?}

A mineral province is defined as a geographic area in which known deposits and occurrences of a given commodity share some common geologic features, but which may also include geologically and geochemically favorable terrain that has a high potential for the occurrence of new deposits (or new types of occurrences) of the specified metal or nonmetal. The accompanying maps, at a scale of $1: 5,000,000(1 \mathrm{in} .=$ approx $129 \mathrm{~km}(80$ miles); $1 \mathrm{~cm}=$ approx $50 \mathrm{~km}$ (31 miles)), are preliminary, generalized, and interpretive overviews inferred from the regional distribution of known metal and nonmetal commodities. Provinces have been outlined for each commodity from plots of resource localities that seem to cluster in or along prominent known or inferred geologic features; in many cases a single province contains more than one commodity. The data points for an individual commodity may represent a mining district, a deposit, or a prospect.

A mineral province may contain one or more operating mines, former major producing deposits, or simply a cluster of unevaluated commodity data points. In a few special cases, an occurrence area has been proposed on the basis of one known deposit or district, with the implication that additional ones may be discovered and a province proposed when more information becomes available. On the basis of current data, some scattered individual data points cannot logically be directly related to a province and are considered to be of only local significance; new data and increased geologic knowledge could, however, change this evaluation. Where appropriate for a given commodity, the distribution of significant associated host rocks or structures is also indicated; these geologic interpretations are abstracted or modified from the "Geologic map of the United States" (King and Beikman, 1974), the "Basement rock map of the United States" (Bayley and Muehlberger, 1968), and the "Tectonic map of North America" (King, 1969). An explanatory table accompanying each map provides a rough evaluation of the resource potential within a given province and illustrates whether the status of geologic knowledge about the commodity province area is adequate or insufficient to assess fully either the resource potential of the province or, possibly, its extent.

\section{COMPONENTS OF PROVINCE MAPS}

If mineral resources are where one finds them, to paraphrase an old saying, the best starting point is a determination of the whereabouts and reasons for commodity concentrations. The atlas of mineral province maps provides framework location data for beginning this search. Special technical and scientific problems of resource occurrences or characteristics are described by commodity specialists for most of the commodities reported in the atlas. As author of this report and editor of the atlas, my objectives have been to develop format and subject goals for the maps and to maintain continuity and balance between individual maps. Each mineral province map includes an explanatory text that gives brief background, supply/demand, and geologic information about each commodity; describes the characteristics of provinces and the size classification and geologic types of deposits; and considers significant fea- 
tures of the major provinces. The economic importance of provinces is evaluated where the data are adequate. The main purpose of this atlas is to emphasize known resource distribution and future potential areas, whether presently economic or not, rather than to document past production; detailed production data are already available for most commodities on U.S. Geological Survey Mineral Investigations Resource Maps (MR series) and in the cited resource literature.

The mineral province maps show the distribution of deposits and occurrences against a background of six geologic regions of the conterminous United States, each of which has distinctive topographic and geologic features that to some degree have influenced the types of resources found within them. The boundaries and names of regions are those introduced by Stanton (1972). The Coastal Plains are low-lying areas bordering the Atlantic and Gulf of Mexico coasts that contain relatively young, generally flat lying, or structurally simple sedimentary rocks and uncomplicated mineral concentrations, formed mainly at the same time as the enclosing rocks. In contrast, the Appalachian belt is topographically higher, mountainous, and is composed of old as well as young complexly folded sedimentary, intrusive igneous, and metamorphic crystalline rocks. Here, some resource materials formed in simple accumulations as the enclosing sedimentary and volcanogenic rocks were deposited. Later, as the belt was subjected to structural stresses and the introduction of molten (igneous) rock-forming materials, more complex types of deposits were formed, such as mineral segregations within the intrusive igneous rocks, or vein-filling and replacement deposits precipitated from circulating hot mineral-bearing (hydrothermal) solutions derived from the cooling igneous bodies. Some host rocks were thermally altered or reconstituted (metamorphosed) to form distinctive contact (skarn) deposits. Even later, erosion of these rocks and deposits locally created residual (placer) accumulations. The Precambrian Shield is an eroded mountainous region of moderate relief composed of ancient, structurally complex, largely metamorphic crystalline rocks that contain a variety of deposits whose igneous, sedimentary, and metamorphic origins are incompletely understood. The Central Plains is a broad region of low to intermediate relief that mainly constitutes the drainage basin of the Mississippi River.
The tributaries are separated locally by uplifted mountainous areas; these mountain cores are commonly composed of exposed or buried ancient crystalline basement rocks on which have been deposited younger flat-lying or locally gently flexed sedimentary rocks. The deposits are varied; some are typical of the crystalline basement, but, by and large, major mineralization represents stratigraphically and structurally controlled (stratabound or stratiform) deposits in rocks of intermediate (Paleozoic and Mesozoic) age that adjoin exposed basement and intrusive-rock centers or occur in the intervening broad basins. The Cordilleran belt, which is extremely varied topographically and geologically, consists of high mountains, deep canyons, extensive plateaus, and broad intermontane valleys, and includes thick forest in some areas and desert wasteland in others. The rocks, of widely varying ages (Archean to Cenozoic), are of intrusive and extrusive igneous, sedimentary, and metamorphic origins. The broad variation in types of Cordilleran belt deposits, which may have been formed when the host rocks formed, inserted into the rocks later, or concentrated when the rocks were destroyed by erosion, is due to a long geologic history of repeated heating and deformational events and of uplift and exposure of rocks and structures. Anomalously, within the Cordilleran belt is the vast Colorado Plateau, an area underlain by simply warped but generally flat lying sedimentary rocks that have been uplifted, faulted, and dissected by erosion.

The mineral deposits and occurrences in the atlas are classed as large or small. Large deposits are those whose combined production, minable minerals, and potentially minable materials exceed a minimum unit value (table 1 ) equivalent to that of the classes of deposits established for a selected group of commodities on U.S. Geological Survey Mineral Investigations Resource Maps, or as estimated by a Geological Survey commodity specialist. These large deposits are subdivided into types of current and past (or potential) producers. Type A deposits include active mines that had substantial production in 1975 (the base year for this atlas), on the basis of commodity specialist information and supported by a worldwide survey of major mining activity (excluding coal) conducted by Mining Magazine (1976). Type B deposits include those major past producers now considered mined out, inactive owing to economic 
TABLE 1.-Comparisons of size, value, and numbers of deposits for selected critical commodities, and their availability and impart dependence in the United States

\begin{tabular}{|c|c|c|c|c|c|c|c|}
\hline \multirow[t]{2}{*}{ Commodity } & \multirow[t]{2}{*}{$\begin{array}{l}\text { Production } \\
\text { units }^{1}\end{array}$} & \multirow[t]{2}{*}{$\begin{array}{l}\text { Approximate } \\
\text { unit } \\
\text { dollar value } 2\end{array}$} & \multicolumn{2}{|c|}{$\begin{array}{l}\text { Comparative minimum size } \\
\text { and dollar value of large } \\
\text { deposit (types } A \text { or } B)^{3}\end{array}$} & \multirow[t]{2}{*}{$\begin{array}{l}\text { Number of active } \\
\text { (type A) deposits } \\
\text { in } 1975^{4}\end{array}$} & \multirow[t]{2}{*}{$\begin{array}{l}\text { Number of } \\
\text { inactive } \\
\text { (type B) deposits }\end{array}$} & \multirow[t]{2}{*}{$\begin{array}{c}\text { Percent import } \\
\text { dependence } \\
1978^{2}\end{array}$} \\
\hline & & & $\begin{array}{l}\text { Units produced } \\
\text { and (or) available } \\
\text { minable mining }\end{array}$ & $\begin{array}{c}\text { Estimated } \\
1978 \\
\text { dollar value }\end{array}$ & & & \\
\hline \multicolumn{8}{|l|}{ Aluminum: } \\
\hline bauxite---------- & Metric ton --.-- & 10 & 625,000 & 6 million & 2 & -- & 93 \\
\hline metal ${ }^{7}$ & Short ton --.-- & 1,000 & 125,000 & 125 million & --- & --- & 10 \\
\hline \multicolumn{8}{|l|}{ Chromium: } \\
\hline chromite - - & Metric ton ----- & $40-160$ & 1 million 40 & 40-160 million &.- & 2 & 92 \\
\hline Cobalt -- & Pound - - & $6-20$ & -- & --- & --- & -- & 97 \\
\hline \multicolumn{8}{|l|}{ Columbium (Niobium): } \\
\hline ore - - & Pound --------- & 3 & --- & --- & -- & 10 & 100 \\
\hline Copper - - & Short ton ----- & 1,300 & 1 million & 1,300 million & $637(5)$ & $>10$ & 19 \\
\hline \multicolumn{8}{|l|}{ Fluorine: } \\
\hline fluorspar ore -.--- & Short ton --.-- & 30 & 2 million & $60 \mathrm{million}$ & 2 & 4 & 82 \\
\hline \multicolumn{8}{|l|}{ Iron: } \\
\hline taconite --.-- & Long ton unit -- & 0.60 & 5 billion & 3 billion & 42 & 44 & 29 \\
\hline Lead - - & Short ton ----- & 680 & 1 million & 680 million & ${ }^{6} 12(9)$ & 13 & 11 \\
\hline \multicolumn{8}{|l|}{ Manganese: } \\
\hline ore - - & Long ton unit -- & 1.40 & 775 million & 1 billion & -- & 5 & 98 \\
\hline Mercury -- & Flask -------- & 158 & 75,000 & 11 million & 1 & 9 & 57 \\
\hline Nickel - - & Short ton ----- & 4,000 & 50,000 & 200 million & 1 & 7 & 77 \\
\hline \multicolumn{8}{|l|}{ Phosphorous: } \\
\hline phosphate rock ---- & Short ton -....- & 17 & 10 million & 170 miltion & 32 & -- & 0 \\
\hline 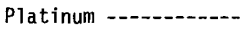 & Troy ounce ----- & 250 & 400 & 100,000 & -- & 9 & 91 \\
\hline \multicolumn{8}{|l|}{ Tantalum: } \\
\hline ore -- & Pound --_----- & 27 & --- & -- & --- & 9 & 97 \\
\hline Tin - - & Metric ton ----- & 13,000 & 3,000 & 40 million & --- & ${ }^{6}(1)$ & 81 \\
\hline \multicolumn{8}{|l|}{ Titanium: } \\
\hline ilmenite -------- & Long ton ----- & 50 & 2 million & 100 million & 6 & 2 & 39 \\
\hline \multicolumn{8}{|l|}{ Tungsten: } \\
\hline ore - & Short ton unit - & 134 & 1.2 million & 160 million & 2 & 6 & 50 \\
\hline \multicolumn{8}{|l|}{ Vanadium: } \\
\hline$v_{2} O_{5}$ & Pound --_--.-- & 3 & 10,000 & 30,000 & --- & 12 & 27 \\
\hline Zinc - & Short ton ----- & 620 & 1 million & 620 million & ${ }^{6} 17(13)$ & 8 & 62 \\
\hline
\end{tabular}

${ }^{1}$ Short ton $=2,000$ pounds $(907.2 \mathrm{~kg})$.

Long ton $=2,240$ pounds $(1016.0 \mathrm{~kg})$.

Metric ton $=2,205$ pounds $(1000.0 \mathrm{~kg})$.

Flask $=76$ pounds $(34.5 \mathrm{~kg})$.

1 troy ounce $=0.0833$ pounds (troy).

Long ton unit $=22.4$ pounds $(10.2 \mathrm{~kg})(46-48$ percent $\mathrm{Mn} ; 63$ percent $\mathrm{Fe})$.

Short ton unit $=20$ pounds $\mathrm{WO}_{3}(9.1 \mathrm{~kg})(16$ pounds $(7.2 \mathrm{~kg}) \mathrm{W}$ metal $)$.

2Data source: U.S. Bureau of Mines (1979).

${ }^{3}$ Size of large deposits based on U.S. Geological Survey Mineral Investigations Resource Maps, where available, or evaluation by province map author(s).

4Sources: U.S. Geological Survey commodity specialist and Mining Magazine (1976).

5Source: U.S. Geological Survey Mineral Investigations Resource Maps, where available.

${ }^{6}$ parenthetical values indicate additional mines that produce commodity as a coproduct or byproduct.

${ }^{7}$ Comparative amount and value of metal theoretically derivable from a large bauxite deposit. 
or technological factors, or having continuing minor production unreported in the survey but identified in the mineral investigation maps, and, in some cases, unmined deposits that contain a large identified but subeconomic resource potential. Together, type A and B deposits represent "elephant country" targets-places where the search for new resources would logically begin. Small deposits and occurrences (type C) are those whose combined production and minable minerals range from none (undetermined) to the minimum set for types A and B. Type C localities comprise present or possible producers and presently unevaluated occurrences, and encompass a broad range of deposits whose production history is limited but which may possibly develop into a higher class, as well as known unproductive or unmeasured, presently subeconomic occurrences.

The density and clustering of small (type C) deposits and occurrences around large (types $\mathrm{A}$ and B) deposits or mining districts within a mineral province may provide a measure of its potential for future production. This distinction between major deposits and the more abundant smaller deposits and occurrences provides an immediate rating of a province's past production history in comparison with its present production status. The proportion of type A deposits on a given map also gives a visual evaluation of the abundance of resources and the capacity for domestic suppliers to meet present requirements for a given commodity. Large type B deposits locate substantial former producers that, for economic or unknown factors, are now inactive; in most cases, these resources have not been exhausted. Thus, regions containing deposits of either type A or B, or of both types, are also geologic terranes that still have a high probability for the discovery of hypothetical resources, both as extensions of known deposits and as new ore bodies concealed in untested ground. On the basis of past experience, however, so great a potential might not be expected for a province that contains only a small number of type $\mathrm{C}$ deposits as for a province that in addition contains one or more type $A$, or even type B, deposits.

Caution: The presence of a large number of type $\mathrm{C}$ deposits may not represent the economic abundance of a commodity. First, these data points indicate the reported presence of the commodity but, more often than not, probably denote subeconomic possibilities, rather than economic realities, that will require further investigation or changes in economic conditions. Furthermore, many of these data were obtained by a diverse group of geoscientists whose primary investigative purposes may not have been resource assessment, and so resource values may not have been recognized or fully reported. Some type C deposits may appear on several province maps where a commodity occurs as a primary, coproduct, byproduct, or presently unrecovered constituent.

Additional information and references to the more specific resource literature on the metal and nonmetal commodities selected for these maps were given by Brobst and Pratt (1973) and the U.S. Bureau of Mines (1976a). National resource issues, to which province maps are relevant, were discussed further by the U.S. Geological Survey (1975).

\section{USE AND USERS OF PROVINCE MAPS}

The resource information on a mineral province map is intended for a wide audience. These maps provide nontechnical users with a simplified visual appreciation of the status of basic data on the availability of mineral commodities, as well as of the importance and need for better information. Legislators and administrators who devise land-use policies and workable new mining and leasing laws, make equitable environmental regulations, or develop and approve foreign agreements should gain added awareness of some of the underlying scientific and technological constraints on domestic-resource supply as well as learn where domestic supplies occur or may be developed, assuming that the required additional resource research is completed. Resource generalizations are also useful to governmental analysts and scientists who must plan and justify resource information and research programs that are responsive to long-term national and industrial needs.

\section{LIMITATIONS AND REVISION OF PROVINCE MAPS}

The province maps in the atlas are considered preliminary because the data-some outdated, some incomplete-were collected for different purposes by many observers. We recognize also that the evaluations for many commodities are not consistent throughout the conterminous United States, nor do they benefit adequately from resource industry expertise and information. 
The small scale of the maps, the consolidated geologic data (presently lumped into broad age, composition, and structure categories), and the possibly inaccurate evaluations, owing to sparse or fragmentary data, may make the generalized analyses on these maps somewhat presumptive. Hopefully, an awareness of these limitations has permitted as accurate a presentation as possible and will provide the stimulus to identify new goals or opportunities for subsequent improved maps.

Meanwhile, if these maps are incomplete or defective, or fall short of fulfilling the stated purposes, constructive advice from their users is welcome so that the data can be further revised and upgraded. Improved maps will be possible once the gaps in information are filled; critical reviews by mineral industry scientists are particularly important. Such improved maps will enable a knowledgeable public to have an impact on national-resource policy decision, particularly those that may result in legislation.

\section{A COMMON DENOMINATOR FOR RESOURCE EVALUATION}

Resource materials have come to be measured in a variety of production units that may make it difficult to understand the relations between units or to make direct value comparisons between commodities with other national assets; all materials, however, have a monetary value that is readily understood. To make the maps understandable and to provide a basis for comparing mineral resources with other national assets, traditional measurements in pounds, units, flasks, ounces, or long, short, and metric tons have been converted to 1978 U.S. dollars on the basis of average prices published by the U.S. Bureau of Mines (1979). Dollar values for specific critical commodities are shown in table 1, which also indicates the orders of magnitude of types $A$ and $B$ deposits for each of the metals or nonmetals. Where a given deposit has produced the commodity as a coproduct, this valuation represents the best estimate for that specific coproduct or byproduct rather than the total value of all production from the deposit. Establishing a value for the metal content of some ores (such as chromite) that are sold in variable-composition grades is a problem, but the averages assumed in these cases should not invalidate the general and limited comparisons drawn.
Although the dollar value of mined minerals provides a standard for discussion of an individual commodity's importance as well as for comparison of one commodity with another, dollar value may not convey the true worth of a mined material. For example, the value of bauxite ore, from which aluminum metal is derived, is about 1 percent of the value of the metal produced therefrom. The varying value of money itself over time is moderated somewhat by the use of $1978 \mathrm{U} . \mathrm{S}$. dollars, which brings past mineral production closer to the perspective of present decisions. Such data often show that the value of current and past domestic production for some mineral commodities is an almost insignificant fraction of one year's industrial demand, whereas for other commodities the resource endowment has been and can be expected to continue to be a substantial part of the Nation's economy. Dollar value is also a possible consideration in comparing the value of a given mineral product in an area with the competing value of the same area for other purposes, in order to assess relative worth in land-use and environmental-impact analyses.

Does the dollar value of a deposit based on the raw material mined represent a true value for such determinations? The answer is no; the ultimate worth of metal and nonmetal minerals to the Nation is much greater than the simple estimated values listed in table 1 . U.S. Bureau of Mines (1978) estimates for nonfuel mineral contributions to the U.S. economy in 1977 (fig. 1) demonstrate this point.

Once processed, domestically extracted materials (valued at $\$ 17$ billion) plus additional imports of raw materials and recycled scrap (valued at $\$ 3$ billion each) achieve a total worth of $\$ 170$ billion, an increase by a factor of nearly $7 \frac{1}{2}$. In turn, when imports of processed mineral materials are combined with these domestically processed materials, a significant but unknown increment attributable to the fabrication and other uses of mineral materials contributes ultimately to the $\$ 1,890$ billion U.S. gross national product. Thus the true value of the extractable materials in a mineral deposit is incalculable in a specific sense because of the substantial values added once mineral materials are processed and used. One should, of course, not lose sight of that added intangible resource value: the possibility of domestic deliverability of a strategic but now subeconomic mineral material when it becomes unavailable elsewhere. 


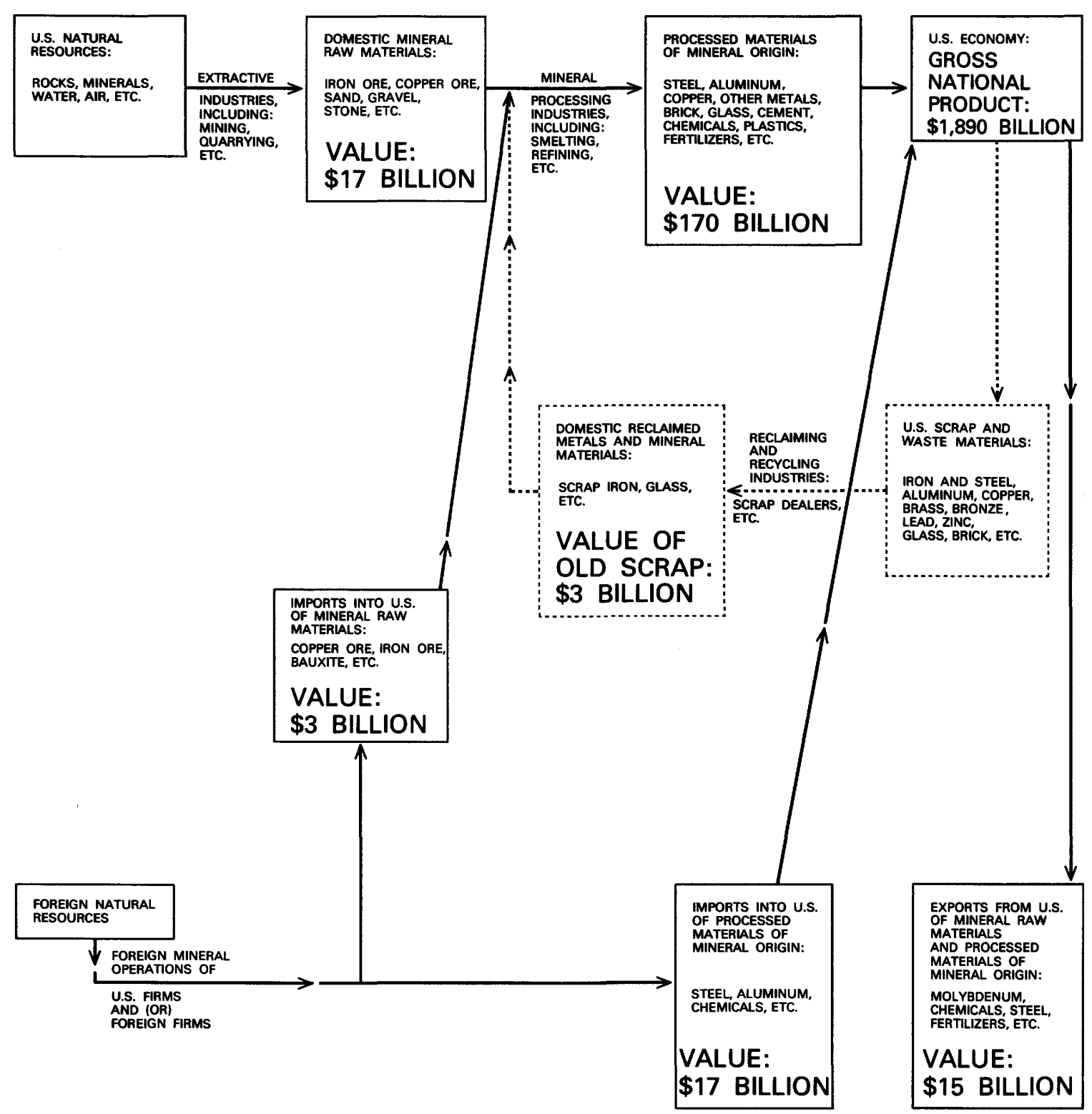

FiguRE 1.-Role of nonfuel minerals in U.S. economy, with estimated values for 1977 (U.S. Bureau of Mines, 1978, p. 17).

\section{COMMENTS ON RESOURCE TERMINOLOGY USED}

Discussion of mineral provinces requires the definition and use of certain technical and often-misunderstood resource terms that in the past have caused confusion among many nonspecialists; this confusion can be eliminated here by the substitution of a simplified terminology for nontechnical study and use of this atlas.
For the benefit of resource specialists, scientists, economists, and mining technologists, the U.S. Geological Survey (1976) has published an official classification of the types of resource categories and defined the precise resource terms to be used in technical communications. For the atlas, however, which in large part is aimed at a nontechnical audience, the resource terms needed to explain core issues are here reduced to three simple 
categories, whose relation can be expressed by the equation

\section{Resources $=$ minable minerals + potentially minable materials}

and which are shown in figure 2 for comparison with the diagram in the official classification (U.S. Geological Survey, 1976, p. A2). Use of these much-generalized terms here does not, however, constitute a change in official policy or a redefinition of the official terminology.

On the province maps and accompanying texts, the term "resources" includes all categories of mineral materials that are currently useful or that may someday become useful. "Resources" thus includes ore in active mines, comparable ore yet to be discovered, and low-grade subeconomic materials that may become economic at some future time. For subeconomic materials, however, a minimum content of a commodity above its clarke (average in crustal rock) distinguishes a potentially minable resource material from average rocks of the Earth's crust, most of which are not yet considered useful commodity sources. A minable mineral is a known usable mineral commodity (such as ore or reserve) that can be extracted economically at the present time. All other resource materials on figure 2 are considered to be potentially minable materials; these materials include all undiscovered minable minerals, as well as subeconomic materials that may become min-

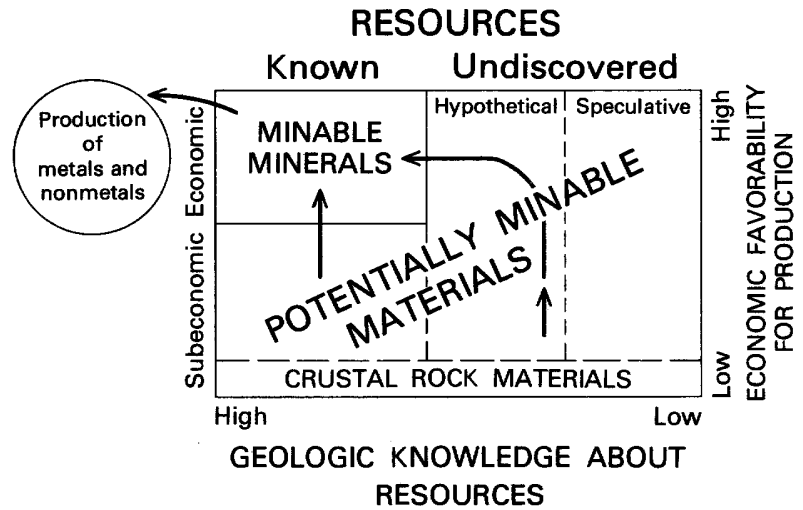

Figure 2.-Simplified mineral-resource terms (modified from U.S. Geological Survey, 1976) and resource area of special concern (fenced). Arrows indicate expected flow of resources from the undiscovered and subeconomic, potentially minable minerals category into the minable minerals category as a result of improvements in geologic knowledge and more favorable economic factors. able under more favorable economic conditions (higher prices) or because of improved technology.

Two other useful terms are subcategories of undiscovered materials (U.S. Geological Survey, 1976): hypothetical, resources that are extensions of known deposits, or expectable deposits in favorable geologic environments elsewhere; and speculative, resources that may occur as wellknown types of deposits in a favorable geologic setting but whose existence has eluded detection, or deposits that may occur in geologic environments as yet unrecognized to be favorable for the occurrence of a specific mineral. On the mineral province maps, hypothetical resource possibilities have been considered but speculative resources have not. Even though speculative resources are beyond the scope of the map data base, they are possibilities that should not be overlooked or discounted. In a successful course of events, as geologic knowledge and economic factors improve, materials flow upward into the minableminerals category in the upper left-hand corner of the diagram (fig. 2) and thus become deliverable to the industrial production system.

\section{WHAT ARE CRITICAL MINERALS?}

The United States has a critical need for resource information on all the commodities listed in table 1 and included on the accompanying mineral province maps. These commodities were selected in part on the basis of recommendations by a joint task force of the Council on International Economic Policy and the National Security Council (Council on International Economic Policy, 1974), and by resource analysts of the U.S. Bureau of Mines (1976a). An explicit definition of a critical commodity from a mineral-resource point of view is difficult, may vary with time and circumstances, and may ultimately depend on whether the available resource can be produced under present or anticipated economic, legal, political, and technological conditions. The following list shows a number of wide-ranging factors that must be considered:

1. The commodity is an essential industrial or strategic material.

2. Sufficient minable quantities of the commodity are not known to occur in the United States.

3. The possibility that the commodity may be geologically available as a potential resource is unknown or undetermined. 
4. Almost no current U.S. production capacity, skilled technicians, or existing technological know-how exists to develop the commodity.

5. A marked increase in use of the commodity is anticipated, such as a new demand to achieve the national goal of increased energy production.

6. Import dependence of the commodity is greater than 50 percent.

7. The known source of the commodity is in a politically unstable international area.

8. The commodity is subject to potential cartel restrictions.

9. Few or poor substitutes for the commodity exist.

10. U.S. resource potential for substitute materials is nonexistent or undetermined.

11. Technology for utilization of substitutes or reclamation from scrap is undeveloped.

12. Irretrievable losses or dissipation in resource use preclude recycling of the commodity.

13. Energy cost to produce the commodity is high, especially for lower grade ores.

14. Production efforts entail environmental hazards or legal prohibitions.

15. Current lack of capital investment in resource industries, because of present low rates of return, can be expected to extend an already long leadtime to production.

\section{A NEED FOR CONCERN ABOUT DOMESTIC RESOURCES}

Although adequate resources of most materials are presently available from world sources, many long-term (5-10 year or more) uncertainties about continued availability exist that prudent nations need to examine and evaluate, one of the most important of which is the capability for selfsufficiency. The future long-term domestic supply of many critical mineral commodities depends on a number of factors, in particular an understanding of their geologic characteristics. For some commodities, the geologic environment is well known and chances for new discoveries are good; for others, knowledge is minimal and thus little is know about their resource potential. The basic supply problem, however, may be more one of deliverability of a critical resource than its existence. A first step toward gaining a measure of national self-sufficiency or understanding the im- possibility of attaining it is systematically to collect knowledge about the availability of domestic resources, particularly those that may be on federally owned lands (Bennethum and Lee, 1975). The metal and nonmetal mineral province maps provide a qualitatively useful, even if incomplete, assessment of specific areas that have resource possibilities in the United States and indicate additional areas that may need more careful and complete examination. From such maps, plans can be made to improve the data base and analytical capability for a more critical evaluation of domestic-resource availability.

\section{THE PRESENT MINERAL-RESOURCE SITUATION}

The economy of the United States has historically had a solid base of domestic mineralresource industries but in recent years has increasingly relied on imports of raw materials. The U.S. Bureau of Mines (1976b) estimated that industry ultimately contributed 19 percent of the gross national product in 1976 by use of both domestic and foreign mineral materials. According to another survey (Mining Magazine, 1976), the United States, which continues to be a major mineral producer, operated 188 (17 percent) of the 1,126 mines (other than coal) that contributed 90 percent of the Western World mineral production in 1975. Domestic production, however, has not kept up with demand, and of 19 critical commodities, the Nation now imports more than 50 percent of 9: aluminum, the platinum group, fluorine, nickel, tantalum-niobium, mercury, titanium, tungsten, and zinc (U.S. Department of the Interior, 1977, p. 24).

Softening of the once much more solid domestic base for industrial self-sufficiency is indicated by these statistics, the list of critical factors mentioned above, and the net import dependence of a group of major imported commodities (tables 1, 2) in 1975 and 1978. These data should excite a greater concern for the uncertainties implicit in import dependence and assumed uninterrupted access to resources from abroad. For some mineral materials, however, self-sufficiency has always been an unsolvable problem because the geologic environment in the conterminous United States is inhospitable for their concentration. The mineral province maps graphically define specific regions in the United States where past and present production has been concentrated and where in- 
TABLE 2.-Net import dependence of selected minerals and metals in 1975

[From U.S. Bureau of Mines, 1976]

\begin{tabular}{|c|c|c|}
\hline Mineral & $\begin{array}{l}\text { Amount } \\
\text { imported } \\
\text { (percent) }\end{array}$ & Major foreign source(s) \\
\hline Columbium - & 100 & Brazil, Thailand, Nigeria \\
\hline Mica (sheet) - - & 100 & India, Brazil, Malagasy \\
\hline Strontium - - & 100 & Mexico, U.K., Spain \\
\hline Manganese - - & 99 & Brazil, Gabon, Australia, South Africa \\
\hline Cobalt & 98 & $\begin{array}{l}\text { Zaire, Belgium-Luxembourg, Finland, } \\
\text { Norway, Canada }\end{array}$ \\
\hline Tanta Ium - - & 95 & Thailand, Canada, Australia, Brazil \\
\hline Chromium -............. & 91 & South Africa, USSR, Turkey, Rhodesia \\
\hline Asbestos - & 86 & Canada, South Africa \\
\hline Aluminum (ores and metal) & 85 & $\begin{array}{l}\text { Jamaica, Surinam, Australia, Dominican } \\
\text { Republic }\end{array}$ \\
\hline Fluorine - - & 82 & Mexico, Spain, Italy \\
\hline Bismuth & 80 & Peru, Japan, Mexico, U.K. \\
\hline Platinum group metals & 80 & South Africa, U.K., USSR \\
\hline Titanium (rutile) - - & 78 & Australia, India \\
\hline Tin - & 75 & Malaysia, Thailand, Bolivia \\
\hline Mercury - & 73 & Canada, Algeria, Mexico, Spain \\
\hline Nickel - & 71 & Canada, Norway \\
\hline Zinc $-1-10-1$ & 64 & Canada, Mexico, Australia, Honduras, Peru \\
\hline 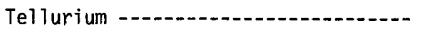 & 59 & Peru, Canada \\
\hline Selenium - - & 58 & Canada, Japan, Mexico \\
\hline Antimony - - & 56 & $\begin{array}{l}\text { South Africa, People's Republic of China, } \\
\text { Bolivia, Mexico }\end{array}$ \\
\hline Tungsten - & 54 & Canada, Bolivia, Thailand, Peru \\
\hline Cadmium - - & 50 & $\begin{array}{l}\text { Mexico, Canada, Australia, Belgium- } \\
\text { Luxembourg }\end{array}$ \\
\hline Potassium - - & 49 & Canada \\
\hline Gold - - & 45 & Canada, Switzerland, U.K., France \\
\hline Gypsum - - & 39 & Canada, Mexico, Jamaica \\
\hline Vanadium -.--. & 36 & South Africa, Chile, USSR \\
\hline 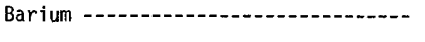 & 35 & Ireland, Peru, Mexico \\
\hline Petroleum (including LNG) ----.-.-- & 35 & $\begin{array}{l}\text { Canada, Venezuela, Nigeria, Saudi Arabia, } \\
\text { Virgin Islands }\end{array}$ \\
\hline Silver - & 30 & Canada, Mexico, Peru \\
\hline Iron - - & 29 & Canada, Venezuela, Japan, Common Market (EEC \\
\hline Titanium (ilmenite) - & 28 & Canada, Australia \\
\hline Salt & 6 & Canada, Mexico, Bahamas, Chile \\
\hline Pumice - & 5 & Greece, Italy \\
\hline Cement - - & 4 & Canada, Bahamas, Norway, U.K. \\
\hline 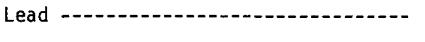 & 4 & Canada, Peru, Australia, Mexico \\
\hline Natural gas - - & 4 & Canada \\
\hline Magnesium (nonmetallic) - & 3 & Greece, Ireland, Japan \\
\hline
\end{tabular}


completely evaluated resource possibilities are known or predicted to exist.

Access to those minable resources that are known to be geologically available in the United States is also uncertain. Can domestic supplies ever provide all consumer needs? The production trends for many mineral commodities (fig. 3) show that in spite of ongoing exploration for and development of new mines, a continued decrease in the overall production trend may be anticipated at the present stage of mineral maturity, as predicted by Hewett (1929). Thus, present levels of domestic production alone will never fill the supply gap (stippled area) so long as consumption mounts. Furthermore, unless mined materials are replaced in the form of expected extensions of known deposits (hypothetical resources) or new mines in virgin mineralized terrains, the domestic production curve will decline at a faster rate than predicted. Even if the present consumption rate were held at a zero-growth level through added effective conservation practices, by reduction of demand, and by introduction of substi- tutes, the resource gap probably could not be closed. Alternative solutions of the supply problem would be a further drop in demand, more effective recycling of scrap materials, increased dependence on imports, and increase in the rate of discovery of new domestic deposits, or a combination. The United States has the potential for production of most critical minerals and other needed mineral materials. We now need to know where they are, in what form and quantity, and at what cost.

\section{THE PROBLEM: PRESENCE IN THE EARTH'S CRUST VERSUS DELIVERABILITY}

Although mineral materials exist in the Earth's crust in great abundance, they may not always be readily deliverable to users. Brooks and Andrews (1974) showed that virtually inexhaustible amounts of most mineral commodities are present in $1 \mathrm{~km}^{3}$ of the average exposed continental crust: aluminum, 200 million; iron, 100 million; zinc, 800,000; and copper, 200,000 metric tons. Such estimates have been used to minimize

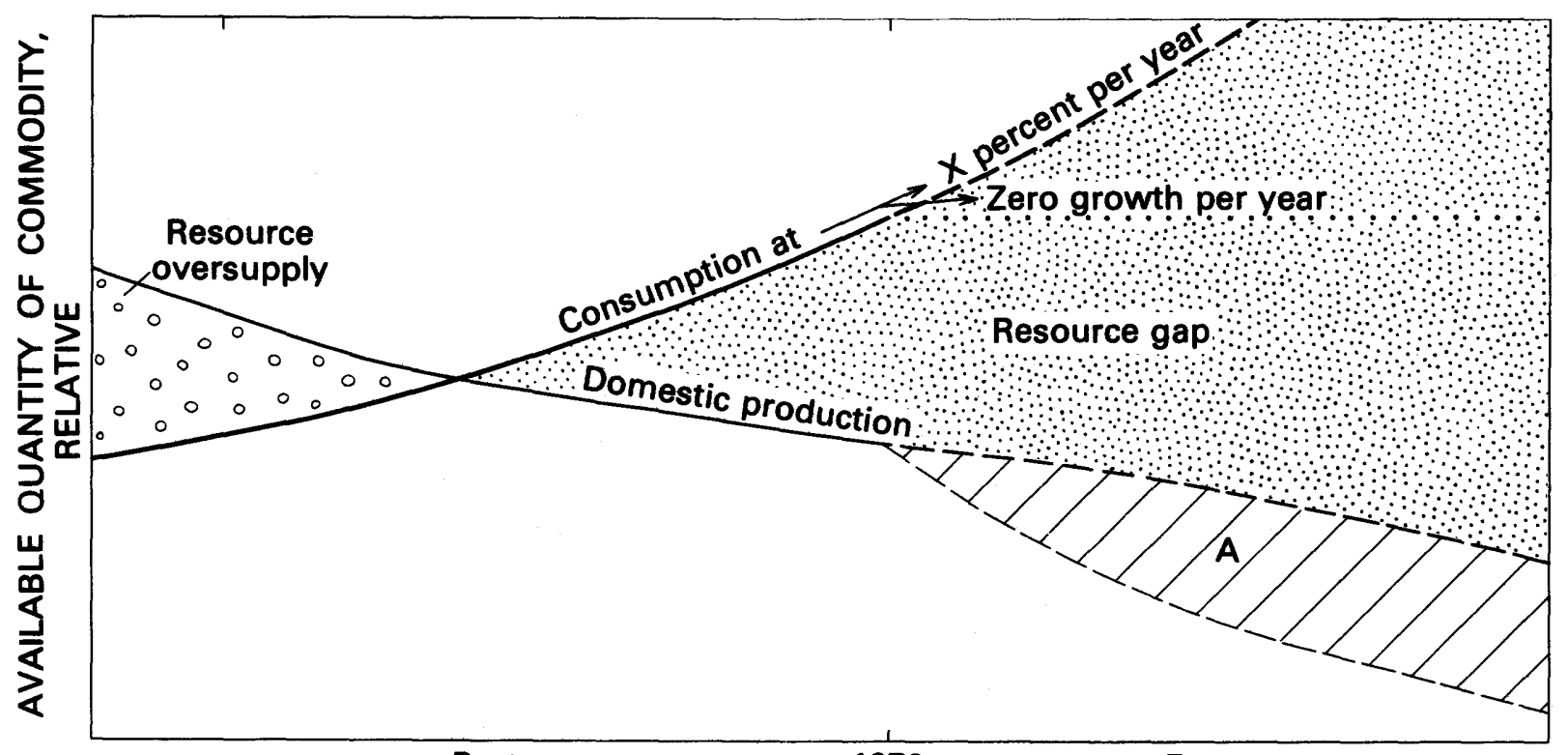

Past

1979

Future

TIME

FIGURE 3.-Diagrammatic projections of past and future national supply and consumption rates for a typical commodity (based on Hewett, 1929), and the resource gap (stippled) that develops where supplies are dependent on a pattern of diminishing domestic production and generally higher current rates of consumption, whether projected at an average percent of increase per year or held at a zero percent (maintain constant level) of growth in the future. The resource bulge (open dots) typifies past domestic production when mineral materials were available for export. Area A (diagonal lines) represents expected depletion of those minable minerals that existed in 1979, as a result of continuing domestic production; the predicted level of domestic production (heavy dashed line) can be maintained only if losses (area A) are replaced by some combination of discovery of hypothetical resources, additional new mines placed in production, conversion of subeconomic resources into minable minerals, or accelerated conservation through recovery from (recycled) scrap materials. 
the opposing Club of Rome (Meadows and others, 1972) concept that the world faces an approaching shortage of many critical mineral materials. Severe technological and economic barriers, however, effectively preclude recovery of most elements at crustal abundance levels (Skinner, 1976). Minable deposits exist where special geologic processes have concentrated the commodity in singular rock types in amounts substantially higher than crustal abundance; such deposits are relatively small and are scattered and buried in the crust much like plums in a pudding. Every reason exists, however, on geologic experience and evidence, to believe that adequate mineral resources will continue to be found as needed; but such resources have finite limits, and their production history shows a peak and eventual decline. Hubbert (1969) clearly demonstrated this trend for oil. Not only are resources limited, nonrenewable geologic entities, but resource production is also uncertain and irregular, both at home and from abroad. Restrictions on the delivery of essential commodities may result from insufficient knowledge or ingenuity in the discovery and production of new resources, or from manmade political, social, environmental, and economic constraints.

There may seem to be little compelling economic urgency at the present time to identify domestic hypothetical-resource targets, in the expectation that increased prices and new technological developments will offset deliverability gaps abroad. But increasing stiff competition for world mineral resources between developed nations, as well as unsettled political conditions in some less developed nations on which the United States depends heavily for supplies, poses ever-present threats of restricted access to critical raw materials. Furthermore, increasing time is required to find, develop, and bring deposits into production, and proportionately higher energy and environmental costs will have as big an impact on the deliverability of foriegn as of domestic resources. Such uncertainties are the basis for an increasing urgency for scientific study and planning to identify and evaluate the future domestic supply situation and its attendant problems.

What can the Nation count on in an emergency? The magnitude of the problem of domestic-resource availability can only be established through systematic assessment of the geologic possibilities for identifying and extend- ing the national-resource endowment. Although deliverability depends on nongeologic factors, a solid base of geologic information on the existence of the commodity to be delivered is required.

\section{GOOD RESOURGE DATA-MORE THAN AN INVENTORY}

Effective national planning requires, first of all, a resource data base sufficient to catalog or inventory past production activity and known "shelf item" mineral resources. The present base for the critical commodities shown on the mineral province maps is extensive but incomplete, often scattered and unevaluated. The formidable task of assembling and evaluating such information for an adequate data base should justify concerted professional action to identify imperfections, fill gaps, correct errors in the present base, and provide the basis and climate for obtaining critical new information. In addition, comprehensive and systematic geologic, geochemical, and geophysical examinations of future resource possibilities in the conterminous United States must be made for all types of critical minerals to avoid overlooking those commodities that exist but which were not of economic interest and do not appear in an inventory of past activity.

\section{RELEVANCE OF GEOLOGIC KNOWLEDGE TO MINERAL AVAILABILITY AND METAL AND NONMETAL MINERAL PROVINCES}

Because the most obvious and readily accessible economic mineral concentrations occurring in or close to the Earth's surface have already been identified and largely consumed, the Nation's future interests can best be served by a more diligent and imaginative use of existing facts and theories to find concealed sources or new modes of occurrence of critical metals and nonmetals. Geologic expertise can provide important insights in this search, but we have only begun to mobilize potential scientific and technological capabilities. Experience demonstrates that undiscovered potentially minable materials will be found in direct proportion to the quality, amount, and organization of scientific research and to the recognition and evaluation of special geologic clues that will lead to the identification and location of new deposits. Ores result from geologic processes both within the crust and on the surface but are created in limited amounts and in restricted areas. The sequential stages in the formation of 
some types of rocks seem to be closely related to the concentration of specific ore materials (Stanton, 1972). Thus a renewed emphasis is needed on metallogenesis, the systematic study of the origin(s) of mineral deposits that occur in the Earth's crust in terms of their unique spatial, temporal, compositional, and structural characteristics.

What are the key geologic features and theoretical possibilities that will provide clues for future mineral discoveries? Several pioneering efforts to find and characterize these geologic guideposts in the Western United States were summarized by Jerome and Cook (1967) and Noble (1970). Guild $(1972,1978)$ has called attention to the stilldeveloping plate-tectonic theory for the formation of the Earth's crust as a new and useful unifying genetic model for the formation of rocks and their characteristically associated ore deposits. On the basis of this theory and supporting geologic, geophysical, and oceanographic evidence, the crust of the Earth is postulated to consist of a number of moving and interacting surface plates, which contain distinctive continental and oceanic crustal rock components (Mitchell, 1976). The plate-tectonic model, though complex and incompletely understood when examined in detail, may lead to new evidence or reinterpretation of the old evidence.

For example, the mineral province maps have already provided a data base on which the location of deposits and occurrences of certain specific commodity types are correlated with their formation in rocks and structures of an old continent and later accreted oceanic and island-arc crusts (Tooker, 1979). These data seem to show a rough tripartite zonation of certain metals and nonmetals, predominantly in crustal rocks of the older continent, younger oceanic crust, and intervening broad overlapping border zone. Mercury, chromium, nickel, platinum, and in part manganese and copper, for example, seem to be closely associated both spatially and time-stratigraphically with mafic, ultramafic, and ophiolitic intrusive rocks, and with volcanogenic sedimentary rocks in oceanic crust. As a generalization, in any one mineral province these metals are concentrated simply as segregation, vein, or stratiform deposits.

Base and ferrous metals and fluorine, on the other hand, seem to be concentrated along the margins of and in a few preferred broad northeast-trending zones within the older conti- nental crust. The occurrence of these metals in complex mixed deposits, often varying widely in age within a province, suggests also that ore materials may have been remobilized during successive heating events in the older continental plate. Tungsten and tin occur in skarn zones and veins, generally closely associated with large granitoid plutons that formed along a broad boundary zone between the older continental and younger oceanic crusts.

On some maps, where appropriate for the particular commodity, we have shown the location of inferred structural boundaries between the older continental and later accreted oceanic and island-arc crusts. This boundary in the Cordilleran belt, as proposed by Stewart (1978), is the supposed west limit of the crust that contains ancient (Archean and Proterozoic) crystalline basement rocks and represents the west edge of the older continental crustal plate at the end of Proterozoic time (table 3). In later (Phanerozoic) time, oceanic-type crustal rocks are believed to have been added by accretion and to have expanded the continent westward. An east structural boundary in the Appalachian belt (Thomas, 1977), marked in part by a prominent fault zone, separates Archean and Proterozoic basement rocks from later eastward additions to the continental mass. This boundary trends northeast into Canada, but its abrupt south end in Alabama coincides with the termination of exposures of the Appalachian belt, which is also concealed by younger Coastal Plain sedimentary rocks. Within the cratonic block (stable central part of the crust), geologists have recognized ancient riftand-flaw (fault) zones that also seem to provide sites for metal and nonmetal concentration (Sawkins, 1976; Tooker, 1979).

The sketchy information on the accompanying mineral province maps suggests other relations

TABLE 3.-Relative age spans of major geologic units used in this report and in province map discussions

\begin{tabular}{|c|c|c|c|}
\hline Era & Eon & & $\begin{array}{c}\text { Approximate duration } \\
\text { (m.y. B.P.) }\end{array}$ \\
\hline Cenozoic & \multirow{3}{*}{\multicolumn{2}{|c|}{ Phanerozoic }} & 65 to present \\
\hline Mesozoic & & & 232 to 65 \\
\hline Paleozoic & & & 600 to 232 \\
\hline Proterozoic $\mathrm{Z}$ ) & \multirow{3}{*}{ Proterozoic } & \multirow{4}{*}{$\begin{array}{c}\text { Precam- } \\
\text { brian }\end{array}$} & 800 to 600 \\
\hline Proterozoic $\mathrm{Y}$ & & & 1,600 to 800 \\
\hline & & & \\
\hline \multirow[t]{2}{*}{ Proterozoic X } & & & 2,500 to 1600 \\
\hline & Archean & & 2,500 and older \\
\hline
\end{tabular}


between resource occurrences and geologic features and provides a tantalizing prelude to more detailed metallogenetic studies, which are needed to refine and provide real meaning for these stilltentative observations. The pattern of mineral province distribution may, in some cases, provide important geochemical clues to discovery of the location and character of buried crustal structures. The goal of metallogenetic research is to provide an increasingly accurate assessment of the resource potential of mineralized regions that will provide the basis for improved exploration technology.

Old data, though, however reworked, are insufficient. A new generation of systematically collected and integrated geologic, geochemical, and geophysical information is vital for completing the mineral resource assessment of the conterminous United States. Such data are essential both to stimulate the development of new resource theory and to make more perceptive use of present-day concepts. Thus a consortium of public, university, and private-foundation geologic research talents, now largely uncoordinated for such purposes, should be mobilized. But these efforts will be insufficient to fill the geologic resource-information gap without substantial help from private industry. Greater participation by the mineral industry, which traditionally has been inhibited from full participation by interindustry competition and proprietary classification of data, is therefore requisite for bringing the full impact of geologic methods to bear on the solution of resource problems.

\section{REFERENCES CITED}

Bayley, R. W., and Muehlberger, W. R., compilers, 1968, Basement rock map of the United States, exclusive of Alaska and Hawaii: Washington, U.S. Geological Survey, scale $1: 2,500,000$.

Bennethum, Gary, and Lee, L. C., 1975, Is our account overdrawn?: Mining Congress Journal, v. 61, no. 9, p. 33-49.

Brobst, D. A., and Pratt, W. P., 1973, United States mineral resources: U.S. Geological Survey Professional Paper 820, $722 \mathrm{p}$.

Brooks, D. B., and Andrews, P. W., 1974, Mineral resources, economic growth, and world population: Science, v. 185, no. 4145 , p. 13-19.

Clark, A. L., Berg, H. C., Cobb, E. H., Eberlein, G. D., MacKevett, E. M., Jr., and Miller, T. P., 1974, Metal provinces of Alaska: U.S. Geological Survey Miscellaneous Investigations Series Map I-834, scale 1:5,000,000.

Council on International Economic Policy, 1974, Special report-critical imported materials: Washington, U.S. Government Printing Office, $49 \mathrm{p}$.
Guild, P. W., 1972, Metallogeny and the new global tectonics, in Mineral deposits: International Geological Congress, 24th, Montreal, Canada, 1972, Section 4, Proceedings, p. $17-24$.

1978, Metallogenesis in the western United States: Journal of the Geological Society, London, v. 135, no. 4, p. 355-376.

Hewett, D. F., 1929, Cycles in metal production: American Institute of Mining and Metallurgical Engineers Year Book 1929, p. 65-93.

Hubbert, M. K., 1969, Energy resources, chap. 8 of National Academy of Sciences-National Research Council, Resources and man: San Francisco, W. H. Freeman and Company, p. 157-242.

Jerome, S. E., and Cook, D. R., 1967, Relation of some metal mining districts in the western United States to regional tectonic environments and igneous activity: Nevada Bureau of Mines Bulletin 69, $35 \mathrm{p}$.

King, P. B, compiler, 1969, Tectonic map of North America: Washington, U.S. Geological Survey, scale $1: 5,000,000$, 2 sheets.

King, P. B., and Beikman, H. M., compilers, 1974, Geologic map of the United States (exclusive of Alaska and Hawaii): Reston, Va., U.S. Geological Survey, scale $1: 2,500,000,3$ sheets.

Meadows, D. H., Meadows, D. L., Randers, Jørgen, and Behrens, W. W., III, 1972, The limits to growth: New York, Universe Books, 205 p.

Mining Magazine, 1976, International mining survey: v. 135, no. 3 , p. 233-244.

Mitchell, A. H. G., 1976, Tectonic settings for emplacement of subduction related magmas and associated mineral deposits, in Strong, D. D., ed., Metallogeny and plate tectonics: Geological Association of Canada Special Paper 14, p. 3-22.

Noble, J. A., 1970, Metal provinces of the western United States: Geological Society of America Bulletin, v. 81, no. 6, p. $1607-1624$.

Sawkins, F. J., 1976, Metal deposits related to intracontinental hotspot and rifting environments: Journal of Geology, v. 84 , no. 6 , p. $653-671$.

Skinner, B. J., 1976, A second iron age ahead?: American Scientist, v. 64 , no. 3, p. $258-269$.

Stanton, R. L., 1972, Ore petrology: New York, McGraw-Hill, $717 \mathrm{p}$

Stewart, J. H., 1978, Rift systems in the western United States, in Ramberg, I. B., and Neumann, E. R., eds., Tectonics and geophysics of continental rifts: Dordrecht, Holland, D. Reidel, p. 89-110.

Thomas, W. A., 1977, Evolution of Appalachian-Ouachita salients and recesses from reentrants and promontories in the continental margin: American Journal of Science, $v$. 277 , no. 10, p. 1233-1278.

Tooker, W. W., 1979, Metal provinces and plate tectonics in the conterminous United States, in Ridge, J. D., ed., Papers on mineral deposits of western North America: Nevada Bureau of Mines and Geology Report 33, p. 33-38.

U.S. Bureau of Mines, 1976a, Mineral facts and problems, 1975 edition: U.S. Bureau of Mines Bulletin 667, 1,291 p. 1976b, Minerals \& materials—a monthly survey: July 1976, p. 3.

1978, Minerals \& materials-a monthly survey: February $1978,63 \mathrm{p}$. 
1979, Mineral commodity summaries 1979: $190 \mathrm{p}$.

U.S. Department of the Interior, 1977, Mining and minerals policy: Washington, U.S. Government Printing Office, 154 p.

U.S. Geological Survey, 1975, Mineral resource perspectives 1975:U.S. Geological Survey Professional Paper 940, 24 p. 1976, Principles of the mineral resource classification system of the U.S. Bureau of Mines and U.S. Geological Survey: U.S. Geological Survey Bulletin 1450-A, p. A1-A5. 
